\title{
Tradisi hajat lembur sebagai media berbagi pengetahuan masyarakat Tatarkarang Jawa Barat
}

\author{
Ninis Agustini Damayani ${ }^{1}$, Encang Saepudin ${ }^{2}$, Neneng Komariah ${ }^{3}$ \\ 1,2,3Program Studi Perpustakaan \& Sains Informasi, Universitas Padjadjaran \\ Jl. Raya Bandung-Sumedang Km. 21, Jatinangor, Sumedang, Jawa Barat, 45363 \\ E-mail: ${ }^{1}$ ninis.agustini@unpad.ac.id, ${ }^{2}$ encang@unpad.ac.id, ${ }^{3}$ neneng.komariah@unpad.ac.id
}

Received: March 2020; Accepted: May 2020; Published: June 2020

\begin{abstract}
The process of sharing knowledge in the 'hajat lembur' tradition requires knowledge management to support the continuity of the tradition. The research aimed to discover the steps of sharing knowledge on 'hajat lembur' traditions. The method used a qualitative case study approach. Data collection was through interviews, discussions, observations, and literature studies. The data validity test process used data triangulation and source triangulation. Data analysis was performed descriptively through the stages of reduction, presentation, and concluding. The data source consisted of six people: two community and religious leaders, three people managing Saung Budaya Tatarkarang, and one government official. Results showed knowledge sharing activities in the process of 'hajat lembur' tradition is a form of gratitude as well as a medium in building human relations with humans, humans with nature, and humans with God, consisted of four stages: socialization, internalization, combination, and externalization. Socialization is in the form of village elders' information delivery about the concept of 'hirup anu hurip' by creating a harmony of life among people, between humans with nature, and humans with their gods. Internalization process, received knowledge is processed and stored in the memory of each individual. Combination process, each member of the community reconfigures explicit knowledge by sorting, classifying, and developing. Externalization, the knowledge in one's mind is conveyed to others by certain media. In conclusion, the Tatarkarang community keep a harmony of life through relations with humans, humans with nature, and humans with God.
\end{abstract}

Keywords: Knowledge sharing; Tradition; Community; West Java

\begin{abstract}
Abstrak
Proses berbagi pengetahuan dalam tradisi hajat lembur memerlukan manajemen pengetahuan untuk menunjang keberlangsungan tradisi tersebut. Penelitian bertujuan mengetahui langkah-langkah berbagi pengetahuan tradisi hajat lembur. Metode yang digunakan kualitatif melalui pendekatan studi kasus. Proses pengumpulan data melalui wawancara, diskusi, observasi, dan studi pustaka. Proses uji keabsahan data melalui triangulasi data dan triangulasi sumber. Analisis data secara deskriptif melalui tahapan reduksi, penyajian, dan penarikan simpulan. Sumber data berjumlah enam orang, yaitu tokoh masyarakat dan tokoh agama dua orang, pengelola Saung Budaya Tatarkarang tiga orang, dan pihak lembaga pemerintah satu orang. Hasil penelitian menunjukkan bahwa kegiatan berbagi pengetahuan dalam tradisi hajat lembur merupakan upaya dalam membangun hubungan antar manusia, manusia dengan alam, dan manusia dengan Tuhan. Hal ini melalui atas empat tahapan, yaitu proses sosialisasi, internalisasi, kombinasi, dan externalization. Sosialisasi berupa penyampaian informasi oleh tetua kampung tentang konsep kehidupan hirup anu hurip dengan mewujudkan keharmonisan hidup antara manusia dengan manusia, manusia dengan alam, dan manusia dengan Tuhan. Proses internalisasi, pengetahuan yang diterima diproses dan disimpan dalam memori setiap individu. Proses kombinasi, setiap anggota masyarakat melakukan konfigurasi pengetahuan eksplisit dengan cara menyortir, mengklasifikasikan, dan mengembangkan. Externalization, pengetahuan dalam benak seseorang disampaikan kepada orang lain menggunakan media tertentu. Simpulan, masyarakat Tatarkarang menjaga keharmonisan hidup melalui komunikasi antar manusia, manusia dengan alam, dan manusia dengan Tuhan.
\end{abstract}

Kata Kunci: Berbagi pengetahuan; Tradisi; Masyarakat; Jawa Barat 


\section{PENDAHULUAN}

Masyarakat adat yang mampu mempertahankan sebuah budaya bergantung pada aspek manusia sebagai pemilik dan penanggung jawab atas keberlangsungan hidup. Manusia sebagai pemilik dan pengembang pengetahuan adat dan budaya secara aktual memiliki kemampuan menciptakan, mengembangkan, membagikan, dan menggunakan dalam kehidupan. Salah satu konsep yang bisa dilakukan dalam pengembangan sebuah budaya melalui berbagi pengetahuan (knowledge sharing) sehingga sebuah budaya bisa tumbuh secara eksponensial.

"Pengetahuan yang dibagi akan tumbuh secara eksponensial. Jika dua orang saling bertukar pengetahuan, keduanya akan mendapatkan informasi dan pengalaman yang tumbuh secara linier. Namun, jika keduanya membagi pengetahuan yang baru kepada orang lain dan mendapatkan umpan balik maka kemanfaatannya menjadi eksponensial" (Helmi \& Arisudana, 2009).

Berdasarkan pernyataan tersebut, dalam proses berbagi pengetahuan diperlukan saling percaya antara pemberi informasi dengan si penerima. Antara beberapa pihak perlu membangun kepercayaan. Berbagi pengetahuan ialah transfer informasi yang tidak sederhana karena dalam prosesnya sendiri terdapat berbagi ide, sikap, nilai, keingintahuan, asumsi, dan harapan. Oleh karena itu, berbagi pengetahuan tidak mungkin terjadi jika kepercayaan tidak terbentuk. Hal tersebut sesuai dengan pernyataan yang disampaikan Helmi and Arisudana (2009) bahwa, "Seseorang akan lebih siap dan bersedia berbagi pengetahuan kepada yang dipercaya dan telah kenal sebelumnya (ingroup) karena didasarkan atas kepercayaan yang tumbuh dalam dirinya" (Helmi \& Arisudana, 2009).

Proses berbagi pengetahuan dalam masyarakat adat tidak terlepas dari konteks komunikasi dalam bentuk dialog interaktif secara individual dan kelompok. Hubungan komunikasi yang terjadi bersifat formal dan nonformal antar anggota masyarakat. Inti dari kedua konteks hubungan komunikasi ini ialah transfer pengetahuan sebuah budaya yang terjadi akan menjadikan penambahan pengetahuan dalam rangka penciptaan, pengembangan, dan penggunaan pengetahuan budaya. Berbagi pengetahuan yang terjadi di kalangan masyarakat adat akan menjadi proses pembelajaran budaya.

Banyak pandangan mengenai batasan berbagi pengetahuan dalam kehidupan berorganisasi.

“Berbagi pengetahuan sebagai proses menyerap pengetahuan dari penelitian dan pengalaman secara sistematis, mengelola, menyimpan pengetahuan dan informasi untuk kemudahan akses, dan memindahkan atau diseminasi pengetahuan, termasuk dalam perpindahan dua arah" (Martini \& Tjakraatmadja, 2011)

Sesuai pandangan ini menggambarkan proses berbagi pengetahuan menjadi sebuah transfer pengetahuan. Dengan demikian, ada dua hal penting dalam proses berbagi pengetahuan, yakni konsep komunikasi dan konsep belajar. Kajian ilmu komunikasi seperti diketahui terdapat unsur komunikasi yang terdiri atas komunikator, komunikan, pesan, dan saluran (media). Dengan demikian, proses berbagi pengetahuan merupakan proses 
komunikasi antara komunikator dengan komunikan. Proses belajar merupakan proses perubahan tingkah laku, di mana terjadi penambahan dan peningkatan pengetahuan kognisi, afeksi, dan konasi.

Pada dasarnya proses belajar di kalangan masyarakat merupakan bentuk kesadaran dalam pengembangan pengetahuan, melalui proses berbagi pengetahuan antar anggota masyarakat. Hal ini menggambarkan terjadinya arus pengetahuan dari pemilik kepada penerima. Hal ini sejalan dengan hasil penelitian di bawah ini.

"Pengembangan pengetahuan diperlukan kesadaran berbagai pihak untuk saling berbagi pengetahuan. Sebuah pengetahuan akan dialirkan dari pemilik kepada penerima. Arus pengetahuan yang terjadi dapat dianalisis menggunakan metode yang sering disebut siklus pengetahuan (knowledge flow). Siklus ini dapat dijadikan acuan dalam pelestarian, bahkan pengembangan suatu pengetahuan. Pola siklus pengetahuan dapat digambarkan dalam pola interaksi yang akan terus bergulir ketika pengetahuan tersebut dikemukakan kepada penerima pengetahuan" (Saepudin, Damayani, \& Rusmana, 2018).

Berdasarkan pernyataan tersebut dapat dikatakan bahwa siklus pengetahuan terjadi melalui proses belajar. Proses pembelajaran dalam organisasi (kelompok/masyarakat) bisa terjadi setiap saat, terutama manakala kelompok tersebut memiliki peristiwa komunikasi yang mengindikasikan perilaku belajar. Perilaku belajar sendiri merupakan gambaran pada diri seseorang atau sekelompok orang yang merasakan adanya penambahan dan peningkatan pengetahuan kognisi, afeksi, dan konasi ketika sedang berdialog (berkomunikasi) dengan orang lain sesama anggota kelompok yang bersangkutan (Yusup, 2012).

Kegiatan perilaku belajar pada masyarakat lebih banyak berupa diskusi ringan melalui kontak komunikasi yang berbentuk lisan. Perilaku belajar seperti ini menjadi pilihan masyarakat melalui pertimbangan kedekatan secara sosial dan kekeluargaan.

“Perilaku belajar merupakan kebiasaan belajar seseorang yang dilakukan secara berulang sehingga menjadi tindakan spontan. Perilaku belajar perlu dibentuk dan disesuaikan dengan tujuan pendidikan. Dengan demikian, tujuan pembelajaran dapat tercapai secara efektif dan efisien" (Rachmi, 2010).

Berdasarkan kegiatan tersebut, peristiwa komunikasi dalam proses pembelajaran lebih banyak terjalin dalam bentuk verbal. Secara umum, masyarakat melalui diskusi ringan tanpa disadari telah memperoleh tambahan pengetahuan dan berbagai macam informasi. Informasi yang disampaikan secara verbal merupakan informasi yang dapat dengan mudah dijelaskan menggunakan lisan, seperti pengalaman anggota, perkembangan masyarakat, referensi, dan lain-lain. Hal ini menjadikan informasi mudah dibagikan kepada masyarakat.

Setiap anggota masyarakat dalam perilaku dan sikap berbagi pengetahuan sangat dipengaruhi norma dan nilai yang diterapkan pada proses penyampaian informasi. Masyarakat dapat melakukan interaksi secara bebas dan terbuka apabila aturan dan norma tidak mengikat secara khusus, misalnya dalam kegiatan tidak formal yakni diskusi yang dilakukan 
cukup santai dan terbuka. Hal tersebut sejalan dengan konsep subjective norm, yakni,

"Sikap yang dipengaruhi oleh persepsi seseorang secara subjektif terhadap situasi tertentu, sehingga muncul sikap setuju atau tidak. Dalam hal ini, norma dan nilai yang dianut seseorang turut menentukan perilaku knowledge sharing yang dilakukannya. Informasi dan jenis pengetahuan apa saja yang akan dibagikan kepada orang lain, sangat ditentukan oleh norma subjektif ini" (Yusup, 2012).

Menurut konsep tersebut, norma dan nilai yang dianut setiap anggota masyarakat berpengaruh terhadap penentuan perilaku berbagi pengetahuan yang dilakukan. Aturan norma dan nilai yang tidak mengikat secara khusus, akan menentukan perilaku setiap anggota yang bebas dan terbuka dalam kegiatan berbagi pengetahuan. Maka, masyarakat dalam kegiatan berbagi pengetahuan penting membangun konteks subjective norm. Adapun pendapat lain berkata.

"Subjective norm merupakan persepsi yang bersifat individual terhadap tekanan sosial untuk melakukan/tidak melakukan perilaku tertentu. Subjective norm dapat ditentukan dan diukur sebagai suatu kumpulan keyakinan normatif mengenai setuju tidaknya terhadap suatu perilaku" (Raharso, \& Tjahjawati, 2014).

Berdasarkan konsep berbagi pengetahuan tersebut, maka berbagi pengetahuan menjadi hal penting di masyarakat, terutama masyarakat pesisir mengenai pengetahuan penanggulangan risiko bencana tsunami. Berbagi pengetahuan, pengalaman mengenai penanggulangan dan pengurangan risiko bencana harus dilakukan melalui proses komunikasi risiko, yang terdiri dari perencanaan kegiatan pra bencana berdasarkan peta potensi bencana yang telah dilakukan identifikasi, kemudian kegiatan saat bencana terjadi, dan kegiatan pasca bencana (Asteria, 2016). Ketiga kegiatan ini harus disebarkan kepada semua pihak yang terlibat dalam kegiatan penanggulangan bencana, yaitu pemerintah, masyarakat yang rawan terdampak bencana, dan pihak yang akan bekerja sama dalam penanggulangan bencana. Dengan demikian, semua pihak yang terkait akan menjadi literer terhadap bencana. Maka, strategi komunikasi kebencanaan yang dibangun akan berisi kegiatan perancangan pesan, pemilihan media, dan teknik penyebaran informasi.

Berkaitan dengan hal ini, masyarakat Jawa Barat di bagian selatan memiliki kearifan lokal yang menjadi tuntunan hidup masyarakat.

“Kearifan lokal merupakan pandangan dan pengetahuan tradisional yang menjadi acuan dalam berperilaku dan telah dipraktikkan secara turun-temurun untuk memenuhi kebutuhan dan tantangan dalam kehidupan suatu masyarakat. Kearifan lokal berfungsi dan bermakna dalam masyarakat dalam pelestarian sumber daya alam dan manusia, pertahanan adat dan budaya, serta bermanfaat untuk kehidupan" (Permana, Nasution, \& Gunawijaya, 2012).

Salah satu kearifan lokal yang berkembang di wilayah Tatarkarang Tasikmalaya mengenai pengetahuan bencana tsunami adalah tradisi raba tahun, sebagai bagian dari tradisi hajat lembur. Tradisi raba tahun dalam "cicirén" atau "tangara" dapat dikenali melalui berbagai 
media yang dipahami masyarakat adat secara turun-temurun. Beberapa contoh "cicirén" atau "tangara" dalam terjadinya bencana tsunami adalah tumbuhnya pohon khas hutan di hutan pesisir, seperti punaga, kipahang, butun, bodol, pandan, dan sebagainya di hutan yang jauh dari pantai. Selain hal tersebut, tanda lain yang menunjukkan akan terjadinya bencana tsunami yang disampaikan hewan (fauna) yang dikenal dengan sebutan "totondén", misalnya "untung ka lembur" "ekek ka lembur" dan lain-lain.

Masyarakat yakin terhadap berbagai kearifan lokal yang semakin kuat dan tertanam dalam hati dan pikiran. Hal ini terjadi karena pengetahuan tersebut tetap dijaga dan dilestarikan melalui konsep berbagi pengetahuan dalam tradisi hajat lembur. Berdasarkan uraian di atas, penelitian ini bertujuan mengetahui langkah-langkah berbagi pengetahuan pada tradisi hajat lembur sebagai upaya pelestarian budaya. Sesuai penelitian ini, maka akan diketahui mengenai langkahlangkah sistematis dalam melestarikan konsep kehidupan yang hirup anu hurip dengan mewujudkan keharmonisan hidup antara manusia dengan manusia, manusia dengan alam, dan manusia dengan Tuhan.

\section{METODE PENELITIAN}

Metode yang digunakan dalam penelitian ini adalah studi kasus melalui pendekatan kualitatif. Pertimbangan peneliti dalam memilih metode kualitatif yakni sifat data yang mampu mempertahankan keutuhan objek, sehingga data dapat dipahami sebagai satu kesatuan yang terintegrasi. Peneliti dalam penelitian kualitatif ini menggunakan instrumen utama untuk mengumpulkan data melalui pendekatan studi kasus untuk menjawab pertanyaan how dan why. Selain itu, peneliti melalui studi kasus memiliki peluang untuk mengontrol peristiwa yang akan diselidiki.

Penelitian menggunakan metodologi kualitatif. Penelitian kualitatif memiliki tujuan.

"Memahami fenomena tentang apa yang dialami oleh subjek penelitian, seperti perilaku, persepsi, motivasi, tindakan, dan lain-lain, secara holistik, dan dengan cara deskripsi dalam bentuk kata-kata dan bahasa pada suatu konteks khusus yang alamiah dan dengan memanfaatkan berbagai metode ilmiah" (Moleong, 2012).

Karakteristik penelitian kualitatif pun dikemukakan Moleong (2012) yakni manusia sebagai instrumen. Kata lain, peneliti merupakan alat pengumpul data utama karena hanya manusia yang mampu memahami secara holistik objek dan subjek penelitian yang dikaji dalam penelitian. Peneliti berperan mengungkap subjek dan objek penelitian secara menyeluruh. Maka, peneliti harus mampu menggambarkan keunikan atau kekhasan dari fenomena yang sedang diteliti.

Hal ini menjadi ciri dari metode penelitian studi kasus. Di mana peneliti harus menerangkan temuan penelitian dari pertanyaan penelitian "mengapa" dan "bagaimana" fenomena tersebut terjadi. Fenomena penelitian yang diteliti ialah tradisi hajat lembur sebagai media berbagi pengetahuan di masyarakat Tatarkarang Jawa Barat. Tradisi ini masih digelar di masyarakat Tatarkarang hingga sekarang. Temuan ini menjadi fenomena yang menarik untuk dikaji karena masyarakat Tatarkarang saling berbagi pengetahuan melalui tradisi hajat lembur.

Peneliti harus mampu menggali data dari pertanyaan, "Mengapa tradisi hajat lembur masih dilakukan di masyarakat 
Tatarkarang?" Setelah peneliti melakukan observasi, ternyata tradisi ini memiliki kearifan lokal dalam menjaga lingkungan desa dari rawan bencana. Desa ini berada di pesisir sehingga rawan terkena gempa dan tsunami. Masyarakat melalui tradisi hajat lembur, bersama-sama memiliki kesadaran untuk menjaga lingkungan desa. Pertanyaan kedua ialah, "Bagaimana tradisi hajat lembur berlangsung di masyarakat Tatarkarang?" Setiap setahun sekali, tradisi ini digelar yang mengandung pandangan hidup bahwa manusia melakukan komunikasi dalam 3 hal, di antaranya komunikasi antar manusia, manusia dengan alam, dan manusia dengan Tuhan.

Peneliti dalam memperoleh data penelitian mengenai tradisi hajat lembur melakukan pengamatan, wawancara, dan mencari dokumen pendukung penelitian, seperti gambar atau foto, termasuk pesanpesan tersirat yang tidak dapat dijelaskan melalui angka. Adapun informan penelitian menjadi sumber data variabel yang peneliti cermati. Teknik pemilihan informan (technique sampling) yang digunakan ialah teknik purposive sampling yakni, "Teknik pengambilan sampel sumber data dengan pertimbangan tertentu" (Sugiyono, 2016). Pada penelitian ini dalam menentukan kriteria informan dipilih seseorang yang mengalami situasi atau kejadian yang berkaitan dengan topik penelitian, yaitu mengenai berbagi pengetahuan dalam rangka pelestarian tradisi hajat lembur pada masyarakat Tatarkarang di Kecamatan Cipatujah, Kabupaten Tasikmalaya, dan masyarakat yang tergabung dalam kelompok budaya masyarakat Tatarkarang. Berdasarkan kriteria informan di atas, maka yang menjadi subjek penelitian berjumlah enam orang dengan rincian dari tokoh masyarakat dan agama dua orang, Pengelola Saung Budaya Tatarkarang tiga orang, dan pihak lembaga pemerintah satu orang.

Pengumpulan data merupakan langkah penting dalam melakukan penelitian untuk menggambarkan dan memaparkan keadaan atau permasalahan yang terjadi. Teknik pengumpulan data merupakan suatu cara atau metode yang dapat digunakan peneliti dalam mengumpulkan data. Maka, peneliti menggunakan beberapa prosedur dalam melengkapi dan memperdalam subjek yang akan diteliti, melalui observasi, wawancara, dan dokumentasi.

Selain itu, uji keabsahan data melalui triangulasi data dan sumber. Analisis data yang digunakan yaitu model interaktif yang terdiri dari tiga tahap yaitu reduksi data, penyajian data, dan verifikasi data (Sugiyono, 2016). Berdasarkan tahapan tersebut, analisis data yang dilakukan melalui pemilihan, penyusunan data secara sistematis dan terukur, sehingga data dapat terorganisasi, deskripsi data melalui penjabaran dan memberikan makna pada data, serta penarikan simpulan.

\section{HASIL DAN PEMBAHASAN}

Berbagi pengetahuan dilakukan seseorang untuk membagikan pengetahuan dan pengalaman kepada orang lain tanpa ada pihak yang merasa dirugikan. Pada kegiatan ini, proses komunikasi yang berlangsung berisi pesan berupa informasi, pengetahuan dan pengalaman individu. Kegiatan berbagi pengetahuan bukan semata memberikan sesuatu kepada orang lain, atau mendapatkan sesuatu dari orang lain sebagai hasil timbal balik. Berbagi pengetahuan merupakan proses 
penciptaan pembelajaran untuk menambah ilmu, pemahaman, dan wawasan baru terhadap suatu hal.

Berbagi pengetahuan dilakukan individu untuk membagi pengetahuan yang dimilikinya kepada orang lain. Saat ini, pengetahuan didapatkan secara formal, dan nonformal melalui interaksi dengan masyarakat sebagai pembentuk struktur sosial, misalnya interaksi interpersonal dan interaksi dalam kelompok. Berdasarkan hal ini, setiap individu dapat mentransformasikan pengetahuan dari pengalaman sehari-hari dan disebar kepada orang lain. Proses komunikasi yang berlangsung saat berbagi pengetahuan berisi pesan yang berupa informasi, pengetahuan dan pengalaman individu. Hal ini karena, "Fokus utama dari knowledge sharing adalah kemampuan seseorang untuk mengeksplisitkan dan mengomunikasikan pengetahuan kepada individu, grup, dan organisasi" (Anna, 2016).

Adapun pendapat lain menuturkan bahwa.

"Knowledge sharing dianggap sebagai proses interaksi sosial antar individu, proses yang tidak dapat dilakukan hanya oleh satu individu. Knowledge sharing merupakan proses saat para individu saling menukarkan pengetahuan, baik pengetahuan tacit maupun pengetahuan eksplisit, untuk menghasilkan pengetahuan baru" (Laili \& Arwiyah, 2019).

Sejalan dengan pendapat tersebut, berbagi pengetahuan pun dikatakan sebagai.

"Proses yang sistematis dalam mengirimkan, mendistribusikan, dan mendiseminasikan pengetahuan dan konteks multidimensi dari seseorang atau organisasi kepada orang atau organisasi lain yang membutuhkan melalui metode dan media yang variatif. Di mana proses ini bertujuan untuk mengoptimalkan penggunaan pengetahuan dan untuk mendorong penciptaan pengetahuan baru sebagai hasil pempelajaran dan kombinasi dari berbagai pengetahuan yang berbeda" (Fauziah, Damayani, \& Rohman, 2014).

Sesuai rujukan di atas, individu mendapatkan dan saling membagi pengetahuan dari masyarakat atau kelompok sosial masyarakat. Salah satu kegiatan yang dilakukan masyarakat Tatarkarang adalah berbagi pengetahuan tentang kesiapsiagaan dalam menghadapi bencana tsunami. Pesan ini disampaikan dalam sebuah tradisi hajat lembur, mengenai pengurangan risiko bencana yang menjadi informasi penting dalam pelaksanaan tradisi ini.

Pesan kesiapsiagaan masyarakat dalam menghadapi bencana disampaikan para tetua kampung (sesepuh kampung) kepada masyarakat melalui prosesi hajat lembur. Pesan ini disampaikan secara verbal dan nonverbal. Adapun gambaran kegiatan tradisi hajat lembur sebagai berikut. Pertama, pelaksanaan tradisi di masyarakat Tatarkarang memiliki latar belakang dua unsur utama, konsep sehat dan konsep lembur (permukiman). Konsep sehat, diyakini masyarakat ini sangat erat kaitan dengan sumber penyakit. Berdasarkan pandangan masyarat, penyakit berawal dari dua sumber utama, yakni sasalad dan penyakit yang datang tidak rasional. Sasalad yaitu penyakit biasa yang datang secara alami, misalnya sakit karena perubahan cuaca, dan lain-lain. Penyakit yang datang tidak rasional (panyakit anu teu sawajarna) merupakan 
penyakit akibat ulah manusia dan makhluk lain.

Hal ini terungkap berdasarkan pernyataan yang diungkapkan sesepuh lembur.

"Sumber payakit nyaeta kahiji sasalad atawa panyakit biasa (panyakit alami), upamana gering téh kulantaran cuaca goréng jeung sajabana. Kadua panyakit anu teu sawajarna, sumber panyakitna téh, anu diakibatkeun tina pagawéan manusa jeung dedemit. "Tenung téngtong rawas gantung, pucuk kawung pating arulang, ngéntép seureuh dina jambé" ieu babasan téh, aya hubungana jeung panyakit anu sumberna ti manusa jeung dedemit tadi. (A. Awangga, wawancara, January 2, 2020).

(Sumber penyakit yaitu pertama penyakit alami, jika penyakit itu disebabkan cuaca buruk dan sebagainya. Kedua, sumber penyakit yang tidak wajar, diakibatkan ulah manusia dan makhluk lain. Tenung téngtong rawas gantung, pucuk kawung pating arulang, ngéntép seureuh dina jambé, babasan ini ada hubungannya dengan penyakit yang bersumber dari manusia dan makhluk lain).

Kedua, landasan pelaksanaan hajat lembur berdasarkan falsafah hidup masyarakat yang meyakini bahwa manusia hidup bersumber dari bumi (taneuh), ialah area kehidupan masyarakat sebagai wahana interaksi sosial sebuah kelompok. Masyarakat Tatarkarang memiliki keyakinan bahwa permukiman merupakan tonggak kearifan manusia dalam kehidupan keseharian yang tercermin dalam pola tindakan. Oleh karena itu, hal ini menjadi wujud syukur terhadap Tuhan Yang Maha Esa. Maka masyarakat diwajibkan untuk melestarikan bumi (ngamumule taneuh) dengan cara menjaga dan memeliharanya. Hal ini sangat kentara dalam pernyataan tetua kampung yang mengandung nilai falsafah hidup masyarakat yang sangat dekat dan bergantung pada tanah (bumi). Pernyataan tersebut yakni,

"Euy, hirup urang nyatu nginum tina taneuh, dahar ngising dina taneuh, dijejek digaley gé dina taneuh" (A. Awangga, wawancara, January 2, 2020).

(Ya, kita makan dan minum berasal dari tanah, makan dan buang hajat pun di atas tanah, manakala meninggal pun kita dikubur ke tanah). Sesuai pernyataan di atas, manusia tidak bisa lepas dari tanah. Hal ini mengandung makna bahwa hidup dan mati manusia bersumber dari tanah. Pernyataan yang mengandung nilai luhur ini merupakan manifestasi dari keyakinan masyarakat mengenai sumber kehidupan manusia. Oleh karena itu, bumi (taneuh) harus dipelihara (dimumule). Hajat lembur merupakan salah satu bentuk rasa syukur masyarakat sekaligus bentuk memelihara perkampungan (ngamumule lembur). Hal ini ditegaskan pernyataan narasumber yang menyatakan bahwa latar belakang (dongdonan) pelaksanaan hajat lembur adalah perubahan populasi masyarakat. Di mana, semakin luas area perkampungan (lembur) pasti semakin banyak penduduknya, yang akan mengubah tatanan kehidupan masyarakat dalam hubungan manusia dengan manusia dan hubungan manusia dengan alam. Berdasarkan perubahan ini, masyarakat mungkin akan lupa dalam tata aturan (adat istiadat). Apabila masyarakat lupa terhadap tata aturan tersebut, maka sumber penyakit akan terbuka terutama 
sumber penyakit yang berasal dari yang tidak rasional (panyakit anu teu sawajarna).

"Salah sahiji anu utama tina dongdonan hajat lembur teh nya eta, lamun lembur geus ngagedéan, tangtuna manusana beuki ngalobaan, anu akibatna tatakrama manusa ka manusa jeung manusa ka alam, geus pasti ka gangguna atawa bisa malaweung, tangtuna panyakit anu sumberna tinu kadua téh potensina gedé pisan. Kajeun nyaho ari balangah mah, komo nu teu nyaho. Tapi lamun kakara babakan mah, biasana cukup ku kokolot lembur waé prosésna téh, bisana, éta kokolot téh sok ngariwayat heula" (A. Awangga, wawancara, January 3, 2020).

(Salah satu utama latar belakang hajat lembur nyaitu kalau perkampungan sudah makin besar, tentu manusia makin banyak. Akibatnya tata krama manusia dengan manusia, manusia dengan alam akan terganggu, pasti penyakit dari sumber kedua potensinya makin besar. Biarkan saja bagi yang mengetahuinya, apalagi yang tidak mengetahui. Namun dalam membuka perkampungan baru, biasanya diproses hanya tetua kampung yang akan memberikan petuah terlebih dahulu).

Selain itu, falsafah pelaksanaan hajat lembur adalah rasa syukur terhadap Tuhan Yang Maha Kuasa atas limpahan rezeki yang diterima masyarakat desa. Kesejahteraan yang diterima masyarakat desa harus selalu disyukuri dengan berbagai bentuk. Salah satu pandangan hidup masyarakat Tatarkarang adalah hirup nu hurip, yang memiliki makna masyarakat desa harus hidup sejahtera. Kesejahteraan kehidupan masyakat akan terwujud bila terbangun hubungan yang harmonis antara manusia dengan manusia, manusia dengan alam, dan manusia dengan Tuhan. Apabila ketiga konsep hubungan ini terjalin baik maka kesejahteraan akan tercipta. Namun, apabila salah satu hubungan tidak harmonis maka kesejahteraan masyarakat sulit tercapai. Hajat lembur merupakan bentuk rasa sukur sekaligus sebagai media dalam membangun hubungan ketiga unsur tersebut. Hal tersebut terungkap berdasarkan hasil wawancara peneliti dengan narasumber.

"Anu jadi cukang falsafahna mah nya eta, ngajalankeun falsafah hirup anu jadi ageman urang kidul nya eta "hirup nu hurip" bae. Tah hajat lembur mah minangka ngajalankeun falsafah hirup eta anu dilarapkeun hirup anu hurip jeung alam sagemlengna, anu dijerona tangtu aya manusa, jin (dedemit) jeung alam sakabeh. Hal eta tujuanna mah teu aya lain supaya salawasna eling ka Gusti Numaha Suci. Numawi, rek lalaku naon wae oge, sok dimimitian ku kecap "mugi Alloh marengkeun" (Sukmana, wawancara, January 3, 2020).

(Yang menjadi falsafah hidup, menjalani kehidupan sebagai pegangan masyarakat Kidul nyaitu "hirup nu hurip". Tradisi hajat lembur menjalankan filosofi ini yang dipraktikkan ke segala aspek kehidupan, yang di dalamnya manusia, jin (dedemit) dan semua alam. Hal ini bertujuan tidak lain untuk selalu mengingat Alloh SWT. Pokoknya, untuk berbuat apa pun selalu diawali ucapan "Semoga Alloh SWT merestui").

Sesuai pernyataan tersebut tergambar bahwa kesejahteraan masyarakat akan terbangun apabila ketiga konsep 
hubungan tersebut terjalin secara harmonis. Selain itu, tergambar pula bahwa pelaksanaan hajat lembur sebagai bentuk kepasrahan jiwa terhadap Tuhan. Pernyataan "Hajat lembur eta tujuanna mah teu aya lain supaya salawasna eling ka Gusti Numaha Suci. Numawi, rek lalaku naon wae oge, sok dimimitian ku kecap "mugi Alloh marengkeun". Peneliti menggarisbawahi bahwa manusia hanya bisa berusaha untuk memperoleh yang diharapkan, namun yang menetapkan keberhasilan tetap Yang Maha Pencipta. Hal ini tergambar dari pernyataan "Numawi, rek lalaku naon wae oge, sok dimimitian ku kecap "mugi Alloh marengkeun."

Berdasarkan pada data lapangan, konsep hirup $n u$ hurip yang diyakini masyarakat Tatarkarang dapat digambarkan dalam gambar berikut.

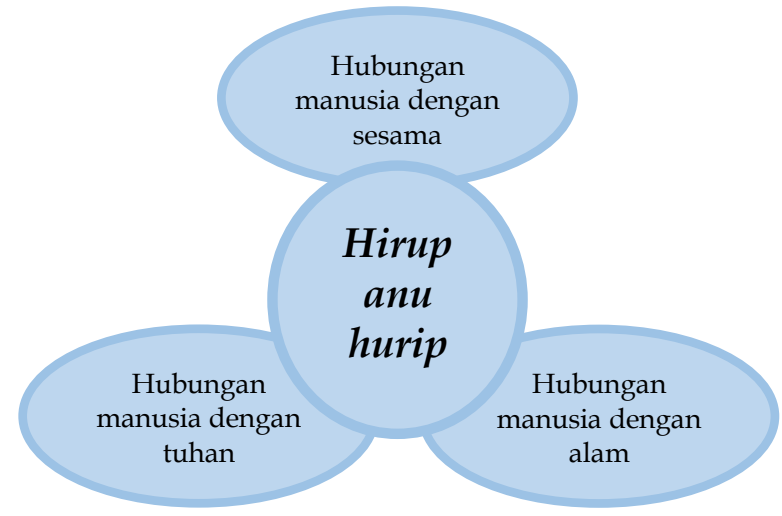

Gambar 1. Konsep hirup anu hurip

Sumber: Hasil penelitian, 2020

Hajat lembur dilaksanakan sesuai kondisi kehidupan pada saat itu. Pertama, hajat lembur terjadi saat tradisi syukuran ketika 1 Muharam bersamaan dengan selesai masa panen besar (mungkas panén). Kedua, hajat lembur berisi pesan untuk menolak bencana (tolak bala) ketika pada masa itu terjadi bencana, sehingga acara berubah menjadi mapag taun yang dilaksanakan malam 1 Muharam.

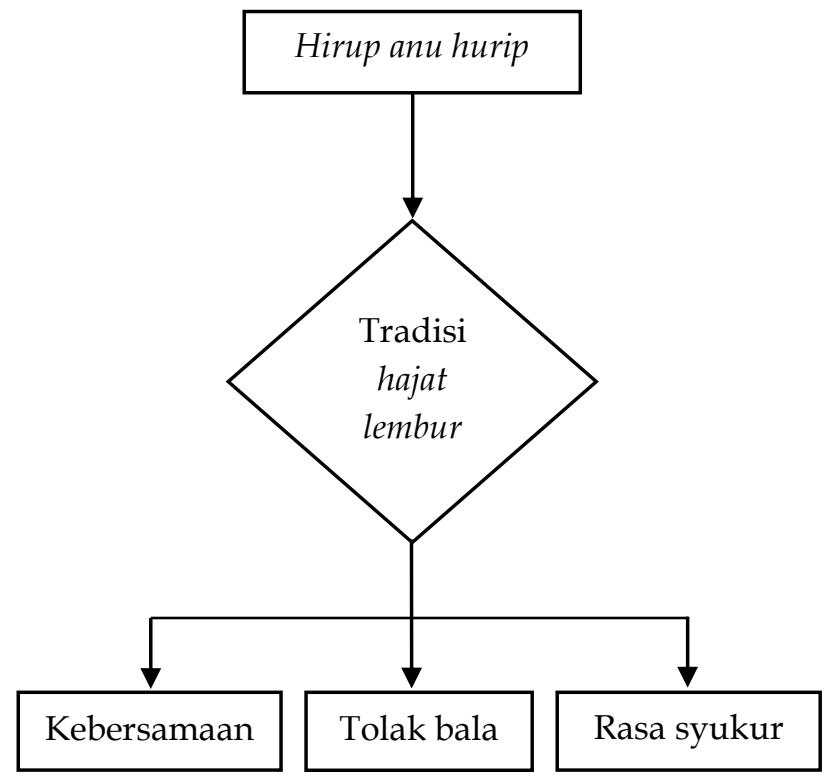

Gambar 2. Falsafah hajat lembur

Sumber: Hasil penelitian, 2020

Keempat, hajat lembur dilaksanakan berdasarkan firasat atau petunjuk yang datang melalui tetua kampung, yang memiliki kemampuan dalam konsep melihat ke depan (narawang kahareup). Tradisi ini berisi ritual bentuk syukur terhadap Tuhan Yang Maha Esa. Salah satu isi prosesi hajat lembur, adalah penyampaian pesan moral dari para tetua kampung kepada masyarakat. Selain itu, masyarakat mengadakan diskusi ringan secara terbuka yang diadakan rutin terkait pesan pemeliharaan kampung. Proses diskusi ini, komunikasi berjalan secara dua arah, tidak ada komunikan dan komunikator secara tetap. Setiap individu diskusi dipersilakan menyampaikan pesan yang ingin disampaikan dan menanyakan suatu hal yang ingin diketahui. Proses komunikasi terjalin cukup spontan, tanpa direncanakan, dan dijadwalkan secara khusus. Pola komunikasi berjalan santai dan terbuka meskipun topik pembahasan diskusi cukup serius.

Hal ini sejalan dari pendapat Heriawan (2016) yang menyatakan bahwa 
peserta diskusi berkomunikasi untuk, "Memenuhi tujuan bersama serta memenuhi sasaran kelompok." Selain itu, terdapat kesepakatan pendapat bahwa kerja sama antara anggota kelompok diskusi adalah unsur yang hakiki dalam diskusi. Kelompok memiliki tujuan bersama dan sasaran untuk menjadi menjadi wadah berkumpul, dan berbagi informasi atau pengetahuan. Kerja sama antara anggota dalam mencapai sasaran ini melalui diskusi ringan, yang menjadi sasaran utama dalam proses berbagi pengetahuan.

Setiap anggota masyarakat dalam menyampaikan pesan dipengaruhi karakter tiap pribadi. Hal ini memengaruhi tingkat keaktifan dalam interaksi, penyampaian informasi, dan pengetahuan. Meskipun antar anggota masyarakat memiliki selisih umur cukup tinggi, tetapi proses penyampaian pesan tidak terpengaruh tingkat usia. Penyampaian informasi dan pengetahuan tidak didominasi senior atau junior, tetapi lebih dipengaruhi karakter masing anggota.

Masyarakat ketika proses berbagi pengetahuan dalam tradisi hajat lembur memerlukan manajemen pengetahuan dalam menunjang keberlangsungan tradisi ini. Seperti yang disampaikan Sunardi, Tjakraatmadja, and Bangun (2015) bahwa secara umum manajemen pengetahuan dapat dijelaskan sebagai langkah sistematik untuk mengelola pengetahuan organisasi dalam menciptakan nilai dan meningkatkan keunggulan kompetitif. Manajemen pengetahuan diartikan sebagai sebuah kegiatan pengelolaan suatu pengetahuan atau kemampuan seseorang dan kelompok/organisasi.

Hal ini seperti yang dikemukakan Yusup (2012) yang mengatakan bahwa,
"Manajemen pengetahuan sama halnya dengan manajemen diri, manajemen perusahaan, manajemen kalbu, manajemen rumah tangga, dan manajemen aspek lainnya". Namun, peneliti perlu menekankan bahwa yang dikelola, direncanakan, dipantau, dikoordinasikan, dikendalikan, dilaporkan segala sesuatunya adalah pengetahuan. Selain itu, "Manajemen pengetahuan terdiri atas tiga proses dasar, yaitu perolehan/akuisisi pengetahuan, berbagi pengetahuan, dan pemanfaatan pengetahuan" (Saepudin, Rusmana, \& Budiono, 2015). Oleh karena itu, dalam kehidupan harus dibangun kesadaran untuk saling berbagi pengetahuan antar anggota kelompok. Hal ini agar pengetahuan individu perlahan menjadi pengetahuan kelompok. Maka, proses berbagi pengetahuan harus terus berjalan dalam kehidupan kelompok atau organisasi.

Pada dasarnya, kunci proses berbagi pengetahuan adalah komunikasi. Yusup (2012) menuturkan bahwa proses pembelajaran organisasi/masyarakat dapat terjadi setiap saat, terutama dalam kelompok yang bersangkutan terdapat peristiwa yang mengindikasikan perilaku belajar. Hal ini ditandai seseorang atau sekelompok orang yang merasakan adanya penambahan atau peningkatan pengetahuan dari sisi kognitif, afektif, dan konatif dalam proses interaksi sosial. Peneliti berikan contoh. Pertama, kita berdialog (berkomunikasi) dengan orang lain sesama anggota kelompok. Kedua, kita mengikuti kegiatan rutin yang diselenggarakan kelompok. Ketiga, kita berkumpul dengan sesama anggota kelompok. Keempat, kita diberikan petunjuk atau arahan pimpinan kelompok/anggota kelompok lain. 
Proses sosialisasi dalam tradisi hajat lembur berjalan secara spontan dan mengalir. Sosialisasi dalam proses penyampaian pengalaman tacit yang dimiliki tetua kampung diberikan kepada masyarakat secara luas. Pengalaman ini berupa pengetahuan atau pengalaman individu yang berkaitan dengan konsep hidup dan kehidupan bermasyarakat. Masyarakat melalui konsep kehidupan hirup anu hurip, berusaha mewujudkan keharmonisan hidup antara manusia dengan manusia, manusia dengan alam, dan manusia dengan Tuhan. Dengan demikian, secara sadar atau tidak sadar telah terdapat pengetahuan baru yang tersebar antar anggota masyarakat.

Anggota masyarakat berdasarkan proses sosialisasi dari interaksi yang terbentuk membagi pengetahuan menjadi dua cara, verbal dan nonverbal. Cara verbal digunakan untuk menjelaskan suatu bahasan yang sedang dibicarakan, atau menjelaskan pertanyaan dari salah satu anggota mengenai topik tertentu. Proses penyampaian pengetahuan tacit berjalan secara verbal menggunakan penyampaian lisan. Kemudian, cara nonverbal digunakan untuk praktik topik pembicaraan yang berkaitan dengan pengetahuan motorik yang menjadi pokok bahasan. Pengetahuan dan pengalaman tacit disampaikan menggunakan metode praktik media tambahan.

Pada dasarnya, kedua cara tersebut saling melengkapi dalam kegiatan diskusi ringan masyarakat. Walaupun begitu, proses sosialisasi dengan cara verbal lebih mendominasi karena tidak membutuhkan media tambahan dalam bertukar informasi. Berdasarkan uraian tersebut, proses sosialisasi pengetahuan merupakan proses interaksi dan komunikasi antar anggota.
Heriawan (2016) dalam proses interaksi dan komunikasi antar anggota, menjelaskan bahwa, "Interaksi mencakup penyampaian maksud dari pemikiran seseorang pemikir ke orang lain baik secara sengaja maupun tidak." Berbagi pengetahuan merupakan kegiatan berbagi dan bertukar informasi yang dilakukan melalui kontak komunikasi. Masyarakat pada umumnya melakukan kegiatan berbagi informasi secara spontan. Di mana tidak semua informasi dan pengetahuan disampaikan secara sengaja. Ada kontak sosial yang tanpa disadari menjadi tempat pengetahuan dan informasi tersebut disebarkan. Interaksi yang terjalin berjalan mengalir apa adanya dengan santai dan terbuka tanpa direncanakan secara khusus.

Perilaku dan sikap setiap anggota masyarakat dalam berbagi pengetahuan sangat dipengaruhi norma dan nilai yang diterapkan pada proses penyampaian informasi. Aturan dan norma tidak mengikat secara khusus, di mana interaksi antar anggota masyarakat dapat berjalan secara bebas dan terbuka. Terkait knowledge sharing behavior, dikatakan bahwa.

"Mengenai subjective norm. Norma dan nilai yang dianut seseorang turut menentukan perilaku knowledge sharing yang dilakukannya. Informasi dan jenis pengetahuan yang mana dan apa saja yang akan dibagikan kepada orang lain, sangat ditentukan norma subjektif ini" (Yusup, 2012).

Menurut konsep tersebut, norma dan nilai yang dianut setiap anggota masyarakat berpengaruh terhadap penentuan perilaku berbagi pengetahuan yang dilakukan. Peraturan berupa norma dan nilai yang tidak mengikat secara khusus telah menentukan perilaku setiap 
anggota yang bebas dan terbuka dalam kegiatan berbagi pengetahuan. Subjective norm merupakan persepsi yang bersifat individual terhadap tekanan sosial untuk melakukan atau tidak melakukan perilaku tertentu. Subjective norm dapat ditentukan dan diukur sebagai suatu kumpulan keyakinan normatif mengenai setuju tidaknya terhadap suatu perilaku" (Raharso \& Tjahjawati, 2014).

Pada umumnya, hubungan yang terjalin antar anggota masyarakat pasca prosesi hajat lembur membaur dan terbuka. Antara satu anggota dengan anggota yang lain terjalin interaksi yang tidak berjarak dan hubungan yang terjalin cukup erat. Hal tersebut membuat rasa kebersamaan tumbuh dan berkembang, dengan keramahan dan keterbukaan yang menciptakan atmosfer cukup hangat. Semua anggota masyarakat membaur satu sama lain. Hal ini disebut sebagai, "Social network" (Yusup, 2012), yang menggambarkan hubungan sosial antar anggota, hubungan sosial melalui media massa, dan internet yang memengaruhi perilaku seseorang dalam melakukan berbagi pengetahuan dan informasi kepada orang lain.

Jaringan sosial yang terbentuk dari hubungan antar anggota cukup luas. Umumnya, social network (jaringan sosial) berjalan secara konvensional melalui interaksi yang berjalan secara langsung antar anggota di kegiatan diskusi ringan dalam kelompok masyarakat. Secara konvensional, tidak banyak anggota yang terlibat interaksi langsung, namun intensitas terbangun cukup tinggi. Setiap informasi dan pengetahuan yang tersebar di kelompok masyarakat disampaikan secara langsung dan spontan sehingga proses penyerapan informasi langsung dan spontan.
Informasi yang diterima secara lisan akan diserap tanpa disadari, kemudian secara alami disimpan dalam memori tiap anggota. Proses yang terbentuk dinamakan internalisasi (internalization), proses mengubah explicit knowledge menjadi tacit knowledge, dan dekat dengan konsep pengalaman karena mengerjakan atau learning by doing.

Konsep internalisasi dalam proses berbagi pengetahuan dalam tradisi hajat lembur dilakukan melalui kegiatan diskusi ringan secara langsung dan spontan. Proses internalisasi mengubah pengetahuan eksplisit menjadi pengetahuan tacit. Hasil dari proses diskusi ringan mengalami proses internalisasi ke pengetahuan tacit, atau pengetahuan yang dalam diri tiap anggota masyarakat.

Maka, informasi yang didapatkan semakin berkualitas, semakin besar pula peluang untuk terserap, yang tersimpan dalam pemahaman dan pikiran anggota masyarakat. Individu dapat menyimpan informasi secara tidak sadar dalam memori dan mendokumentasikan dalam bentuk catatan atau rekaman audio. Setelah itu, informasi dan pengetahuan yang berkualitas, penting disimpan atau bahkan digali lebih lanjut untuk memperoleh informasi tambahan.

Tiap individu yang telah menyerap informasi dan pengetahuan kemudian mengolah, mengelola, dan mengombinasikan informasi. Tiap individu akan mengalami proses pengelolaan dan pengolahan informasi yang berbeda. "Kombinasi merupakan rekonfigurasi pengetahuan eksplisit dengan cara menyortir, mengklasifikasikan, dan mengembangkan semuanya melalui organisasi" (Yusup, 2012). Tiap individu melakukan proses 
kombinasi dan mengolah pengetahuan eksplisit yang diterima dalam proses knowledge sharing.

Tingkat kelompok individu pun terjadi proses kombinasi, yaitu konversi eksplisit ke eksplisit dengan menerapkan langsung informasi tersebut pada instrumen. Informasi dan pengetahuan yang didapatkan awalnya dilakukan identifikasi terlebih dahulu kemudian dicoba dalam aktivitas kehidupan masyarakat. Selain itu, informasi dan pengetahuan yang didapatkan dalam tahap kombinasi akan dibandingkan dan diklasifikasikan dengan pengetahuan yang sudah didapatkan sebelumnya.

Adapun dalam proses internalisasi, kualitas informasi sangat memengaruhi proses kombinasi. Informasi yang semakin berkualitas atau tinggi nilainya, akan diolah lebih lanjut untuk diterapkan dan dikembangkan dalam berbagai macam kebutuhan aktivitas anggota masyarakat, contohnya informasi praktis. Oleh karena itu, proses penerapan merupakan faktor penting dalam tahap pengelolaan pengetahuan yang diterima. Hal ini melalui identifikasi sebagai proses kombinasi, yaitu konfigurasi pengetahuan eksplisit dengan cara menyortir, mengklasifikasikan, dan mengembangkan informasi melalui organisasi.

Masyarakat dalam proses kombinasi mengembangkan pengetahuan yang dimiliki untuk meningkatkan pengetahuan. Praktiknya sendiri cukup beragam. Secara umum, informasi dan pengetahuan yang sudah diserap dan diolah kemudian diterapkan untuk dikembangkan dalam meningkatkan pengetahuan. Maka, wawasan setiap anggota masyarakat dipengaruhi proses penerapan dan pengembangan informasi.
Proses kombinasi dapat disebut pula sebagai proses, "Knowledge utilization" (Lumbantobing, Sule, Tjakraatmadja, Yunizar, \& Purwanti, 2015). Knowledge utilization adalah proses yang dilakukan untuk mendorong dan memfasilitasi organisasi memanfaatkan knowledge yang dimiliki. Masyarakat dalam mencapai tujuan hidup erat kaitannya dengan informasi dan pengetahuan yang diterima. Maka, dapat dikatakan bahwa knowledge utilization mendukung dalam tercapainya tujuan hidup masyarakat.

Salah satu bentuk knowledge utilization dari kegiatan berbagi pengetahuan antar anggota masyarakat adalah kemampuan praktis atau teknis, dan nonteknis mengenai kehidupan masyarakat. Selain itu, pelaksanaan berbagi pengetahuan pun melibatkan hubungan intrapersonal antar anggota. Di mana, anggota masyarakat semakin sering melakukan interaksi, berbagi informasi dan pengetahuan, maka semakin terjalin hubungan sosial dalam kehidupan masyarakat.

Masyarakat yang bersedia berbagi informasi, tentu bersedia menyebarkan informasi dan pengetahuan yang dimiliki kepada orang lain. Proses penyebaran informasi berjalan secara langsung dan spontan dengan bentuk yang tidak formal, serupa dengan proses penyerapan informasi. Umumnya, proses penyebaran informasi dan pengetahuan dalam kegiatan masyarakat berjalan tanpa disadari sehingga interaksi pun berjalan secara alami.

Ketika terjadi penyebaran informasi maka berlangsung pula proses externalization, yakni proses konversi pengetahuan tacit menjadi eksplisit. Yusup (2012) mengatakan, “Jenis pengetahuan yang dipicu oleh dialog atau refleksi kolektif dan sering lahir atas dasar analogi 
dan metafora yang menerjemahkan pengetahuan tacit ke dalam prosedur atau dokumen, termasuk melalui proses komunikasi bermedia."

\section{Externalization merupakan proses} perubahan pengetahuan dalam bentuk tacit menjadi pengetahuan yang explicit, pengetahuan dalam benak seseorang yang disampaikan kepada orang lain menggunakan media tertentu. Pada masyarakat, konsep externalization banyak terjadi dalam kegiatan diskusi ringan, yang penyebarannya berbentuk verbal melalui penyampaian lisan secara langsung. Proses konversi pengetahuan sendiri berjalan secara lisan, pengetahuan tacit diterjemahkan menjadi eksplisit melalui penyampaian verbal. Bentuk nonverbal disampaikan langsung dalam kegiatan masyarakat melalui media tambahan instrumen musik berupa simbol suara. Kemudian, externalization dari pengetahuan tacit diterjemahkan menjadi pengetahuan eksplisit berupa catatan teks, atau rekaman audio yang disampaikan secara langsung dan tidak langsung.

Konsep externalization pada proses berbagi pengetahuan dalam tradisi hajat lembur adalah menerjemahkan pengetahuan setiap anggota berupa penyampaian lisan kepada anggota masyarakat lainnya. Dengan demikian, proses berbagi pengetahuan pada tradisi hajat lembur telah menggambarkan proses penciptaan pengetahuan. Hal ini perlu dibangun saling percaya individu dengan individu lain dan individu dengan organisasi. Rasa saling percaya yang tidak terbangun akan mengakibatkan tingginya kompetisi antar individu sehingga semakin rendah modal intelektual dalam organisasi. Maka, "Nilai kebersamaan (share values), yang disusun bersama-sama individu harus menjadi landasan yang dipercaya untuk meraih cita-citanya. Budaya saling percaya yang dilandasi nilai kebersamaan akan mendorong terciptanya jejaring (network) dan aliansi strategis (strategic alliance) yang sinergis" (Saepudin, Rusmana, \& Budiono, 2016).

\section{SIMPULAN}

Masyarakat Tatarkarang Cipatujah mempertahankan tradisi hajat lembur dengan seluruh nilai yang terkandung di dalamnya. Hal ini terdapat dalam konsep kehidupan hirup anu hurip yang tersampaikan secara lugas dan mendalam. Masyarakat Tatarkarang memahami nilai luhur pelaksanaan hajat lembur melalui empat tahapan, yaitu proses sosialisasi, internalisasi, kombinasi, dan externalization. Konsep ini merupakan perwujudan keharmonisan hidup antara manusia dengan manusia, manusia dengan alam, dan manusia dengan Tuhan. Kehidupan harmonis sesama manusia terbangun melalui sikap saling menghormati dan menghargai. Setiap anggota masyarakat dapat mengakui dan menghargai keberadaan masyarakat lain sehingga hubungan sosial (rasa simpati dan empati) dapat terbangun melalui konteks sosial yang saling memperhatikan kepentingan bersama. Adapun hubungan manusia dengan alam terbangun. Apabila masyarakat memiliki kesadaran yang tinggi bahwa alam harus dijaga kelestariannya, tidak semena-mena dalam menggali potensi alam. Manusia dapat hidup sejahtera dari alam, namun alam yang tidak dilindungi tidak akan memberikan manfaat bagi kehidupan manusia. Hubungan harmonis manusia dengan Tuhan melalui proses hajat lembur, di mana masyarakat sadar akan keberadaannya di dunia ini. Tetua kampung menyampaikan bahwa manusia 
diciptakan untuk mengabdi pada Tuhan dengan mengikuti seluruh ketentuan yang telah ditetapkan. Dengan demikian, masyarakat menjadi lebih sadar mengenai apa, siapa, dan bagaimana dirinya di dunia ini. Masyarakat melalui proses berbagi pengetahuan menerima informasi untuk diserap tanpa rasa terpaksa bahkan tanpa disadari. Informasi dan pengetahuan yang diterima lisan diserap secara alami dan disimpan dalam memori tiap anggota agar terjadi internalisasi dalam diri dan jiwa masyarakat. Konsep internalisasi dilakukan dalam kegiatan diskusi ringan secara langsung dan spontan. Pengetahuan ini tersimpan menjadi pengetahuan berupa pemahaman dalam diri tiap anggota. Kemudian menuju tahap pengolahan, pengelolaan, dan mengombinasikan. Setiap anggota masyarakat akan melakukan konfigurasi ulang pengetahuan eksplisit melalui penyortiran, pengklasifikasian, dan pengembangan semuanya. Dengan demikian, proses berbagi pengetahuan pada tradisi hajat lembur, menggambarkan terjadinya penciptaan pengetahuan yang perlu dibangun saling percaya baik antar individu dengan individu lain, dan antar individu dengan organisasi. Peneliti berharap hasil penelitian ini dapat dijadikan rujukan untuk penelitian lebih lanjut mengenai model manajemen pengetahuan sebagai langkah pelestarian budaya.

\section{DAFTAR PUSTAKA}

Anna, N. E. V. (2016). Step by step strategi penerapan knowledge sharing untuk perpustakaan di Indonesia. Edulib, 6(1), 41-50. https:/ / ejournal.upi.edu/index.php/e dulib/article/view/5001/3566

Asteria, D. (2016). Optimalisasi komunikasi bencana di media massa sebagai pendukung manajemen bencana. Jurnal Komunikasi: Ikatan Sarjana Komunikasi Indonesia, 1(1), 1-11. https://doi.org/10.25008/jkiski.v1i1.3 0

Fauziah, M. R. N., Damayani, N. A., \& Rohman, A. S. (2014). Perilaku knowledge sharing multi bahasa pada komunitas fakta bahasa. Jurnal Kajian Informasi \& Perpustakaan, 2(2), 87-102. https://doi.org/10.24198/jkip.v2i2.11 643

Helmi, A. F., \& Arisudana, A. (2009). Kepemimpinan transformasional, kepercayaan dan berbagi pengetahuan dalam organisasi. Jurnal Psikologi, $36(2)$, 95-105. https://scholar.google.co.id/scholar?c ites $=17517450565629054225 \&$ \&as_sdt $=2$ $005 \&$ sciodt $=0,5 \& \mathrm{hl}=\mathrm{id}$

Heriawan, S. (2016). Pola komunikasi kelompok pada komunitas scooter "Vespa" dalam menjalin hubungan solidaritas: Studi deskriptif kualitatif pada kelompok komunitas Ikatan Scooter Wonogiri di Wonogiri (Skripsi) [Universitas Muhammadiyah Surakarta, Surakarta].

http:/ / eprints.ums.ac.id/43913/

Laili, R. N., \& Arwiyah, M. Y. (2019). Pengaruh knowledge Sharing Terhadap Kinerja Karyawan di PT. Telekomunikasi Indonesia Witel Bandung. Sosiohumanitas, 21(2), 98107.

http://journal.unla.ac.id/index.php/s osiohumanitas/article/view/1248/82 8

Lumbantobing, P., Sule, E. T., Tjakraatmadja, J. H., Yunizar, \& Purwanti, J. (2015). Leadership behavior, perceived organizational support, knowledge sharing intensity, 
and knowledge satisfaction: Study on The Headquarters of 3 State-owned Enterprises that implement knowledge management. In M. Garlatti, A., \& Massaro (Ed.), European Conference on Knowledge Management (pp. 484-495). Academic Conferences and Publishing International

Ltd. http:/ / toc.proceedings.com/27956we btoc.pdf

Martini, L., \& Tjakraatmadja, J. H. (2011). Berbagi pengetahuan di institusi akademik. Journal of Technology Management, 10(2), 196-211. https:/ /journal.sbm.itb.ac.id/index.p $\mathrm{hp} /$ mantek/article/view/140/131

Moleong, L. J. (2012). Metode penelitian kualitatif. Bandung: Remaja Rosdakarya.

Permana, C. E., Nasution, I. P., \& Gunawijaya, J. (2012). Kearifan lokal tentang mitigasi bencana pada masyarakat Baduy. Hubs-Asia, 15(1), 67-76.

http:/ /hubsasia.ui.ac.id/old/index.ph p/hubsasia/article/view/954/46

Rachmi, F. (2010). Pengaruh kecerdasan emosional, kecerdasan spiritual, dan perilaku belajar terhadap tingkat pemahaman akuntansi: Studi empiris pada mahasiswa akuntansi Universitas Diponegoro Semarang dan Universitas Gajah Mada Yogyakarta (Skripsi) [Universitas Diponegoro, Semarang]. https:/ / scholar.google.co.id/scholar?c ites $=11960015509034840695 \& a s \_s d t=2$ 005\&sciod $\mathrm{t}=0,5 \& \mathrm{hl}=\mathrm{id}$

Raharso, S., \& Tjahjawati, S. S. (2014). Perilaku berbagi pengetahuan (knowledge sharing) karyawan minimarket. Sigma-Mu, 6(2), 43-64. https://doi.org/10.35313/sigmamu.v6 i2.884
Saepudin, E., Damayani, N. A., \& Rusmana, A. (2018). Model literasi budaya masyarakat Tatarkarang di Kecamatan Cipatujah Kabupaten Tasikmalaya. Berkala Ilmu Perpustakaan Dan Informasi, 14(1), 1-10. https://doi.org/10.22146/bip.33315 Saepudin, E., Rusmana, A., \& Budiono, A. (2015). Model manajemen pengetahuan sebagai bentuk diseminasi informasi tanaman obat herbal dan tanaman obat keluarga: Studi kasus di Desa Cisondari Kecamatan Pasirjambu Kabupaten Bandung. Sosiohumaniora: Journal of Social Science and Humanities, 17(2), 100-106.

https://doi.org/10.24198/ sosiohuma niora.v17i2.7297

Saepudin, E., Rusmana, A., \& Budiono, A. (2016). Penciptaan pengetahuan tentang tanaman obat herbal dan tanaman obat keluarga. Jurnal Kajian Informasi $\mathcal{E}$ Perpustakaan, 4(1), 95-106. https://doi.org/10.24198/jkip.v4i1.11 633

Sugiyono. (2016). Metode penelitian kuantitatif, kualitatif dan $R \quad \mathcal{E} D$. Bandung: Alfabeta.

Sunardi, O., Tjakraatmadja, J. H., \& Bangun, Y. R. (2015). Human capital traits and informal knowledge sharing: The role of reciprocity norm, mutual trust, and cultural interpretation perspective. International Journal of Knowledge Management Studies, 6(2), 123-135. https://doi.org/10.1504/IJKMS.2015.0 71759

Yusup, P. M. (2012). Perspektif manajemen pengetahuan informasi, komunikasi, pendidikan, dan perpustakaan. Jakarta: Rajawali Pers. 
